\title{
高速抄紙機用セラミックカバーの選択*
}

\author{
ドイッ国 セラムテック株式会社 工学士 K. D. フックス，OP．ラング**
}

\section{Recent Experiences in the Selection of Modern Ceramic Covers for High Speed Paper Machines}

Karl Dieter Fuchs and Peter Lang

CeramTec AG

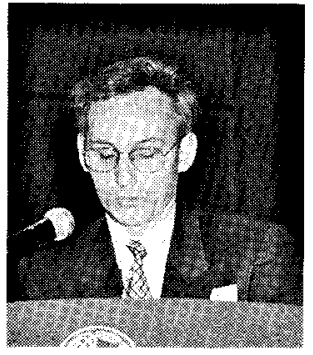

P. ラング**

** (写真竬)

K. D. フックス氏の原稿

を日本語で講演する同社日

本代表P.ラング氏

Modern principles of sheet-forming systems like Hybrid Formers and Gap Formers could be realized only because new components and materials with specific properties are available today.

With the examples of a dewatering and forming shoe with curved formation length and a two slotted felt suction cover, the selection criterious necessary for ceramic covers in modern Paper Machines will be explained.

When producing Fine Papers with heavy filler load the wear resistancy of modern ceramic materials can be an even more important selection criterion than the heat resistancy factor.

Studying the Tribosystem involving the factors fabric, ceramic cover and fillers more closely, we find the fabric wear and the drive load consumption of a sheet former mainly determined by the filler and the ceramic material in use.

When using filler materials, considered from a mineralogical point of view, consisting of hard and adrasive substances like ground calcium carbonate, fabric and cover wear is determined by the abrasiveness of the filler material and the surface characteristic of the ceramic material.

We can prove, that fabric and cover wear are determined more by the particle size and particle size distribution than by the quantity of fillers in use. The percentage of pores, the diameter of pores and the pore distribution in the caramic cover's suface play a dominating role in the wearing mechanism, too.

With ceramic cover materials it is now possible to measure the surface porosity with an interactive picture analysis system. This makes it possible to give exact statements about

\footnotetext{
*平成 9 年度年次大会講演 (講演 No.B 1-19)
} 
pore nombers, pore sizes and pore size distribution. Today this IBAS surface porosity measurement is an important supplement to the previously known measuring methods with which the surface of ceramic covers are described and defined. Now it is possible to give clear statements about the diameter relation of filler particle and cover pore.

The manufacturers of fabrics, fillers and ceramic covers now can play an active role in optimizing their products further to assist the paper makers' efforts in achieving a higher productivity in modern sheet formers.

Keywords : Ceramic, ceramic cover, dewatering element, wear, high speed

\section{1.はじめに}

アルミナ系セラミック・フォイルやサクション・ボ ックス・カバーが, 1960 年代の半ばに日本の抄紙機 に取付けられた時, 関係者にはセラミックの脱水及び 地合形成機器が，日本においてもぺーパー・マシンの 主要な標準設備になるとは，考えられてはいなかった。 それ以来, 地合形成方式の設計は絶えず研究・開発さ れてきた。そして，プレス・パートの一部を含むウエ ット・パートの開発は, 特筆に值するものである。こ の研究・開発の主な理由は, この独特な地合形成方式 によってのみ，紙の生産において最大の経済性と最高 の品質を得られることが評価されたからである。

今日，ハイブリッド・フォーマーやギャップ・フォ ーマーのような高性能シート・フォーミング・システ ムには, 例えば曲線状の面を持った脱水・フォーミン グ・シュー, 調節が可能なフォーメーション・ストリ ップ付きのフォーマーがある。或いはまたプレス・パ ートでは, フェルト・コンディショナー及びュール・ ボックスとしての, 殁ど全てのと言つてよい程のサク ション・チューブがある。未だかつてない程多く, 今 日これらの機器はファイン・セラミックを使用してい る。ペーパー・マシン・デザイナーや製紙会社にとつ てセラミックの選択の基準になるものは，それぞれの 使用条件において, 要求される機能を満足させるファ イン・セラミックの材質である。もしペーパー・マシ ンの使用条件での機械及び熱的条件が分かれば，最も 経済的なセラミック・カバーを選択することが出来る。

使用条件が変らない限り, 七ラミックの機能特性は 出来る限り寿命の長いものにする。使用条件が変れば 一般的にはセラミックの機能もそれに伴って変る。一 つ或いはそれ以上の材質特性が, ひとたび限界に達す るか或いは限界を突破したら，もはやセラミックは正 しく機能しない。今や他のセラミック, 或いは新しい 特性を持ったセラミックが要求されている。勿論この 事はペーパー・マシン・デザイナーや製紙会社が, 他
の選択基準を考えねばならないことを意味するもので ある。

我々は我々の経験に基づいて, 最新型ペーパー・マ シンの設計原理が実用化出来ることをあくまでも追及 していくものである。何故ならば我々のセラミック産 業が適切な特性を持った機能セラミックを，開発する ことに成功したからである。

\section{2. 熱応カファクターの重要性}

図 1 は現在ファイン・セラミックと呼んでいるもの を示す。ファイン・セラミックは金属酸化物, 金属炭 化物, 金属窒化物, 及びそれらの化合物を主成分とす る硬い多結晶物質である。ワイヤー・パート及びプレ ス・パートにおける脱水機器は設計とプロセスの原理 を決定するトで，ファイン・セラミックの果たす役割 の限度を示子なめに使用される。逆説的に言えば，フ

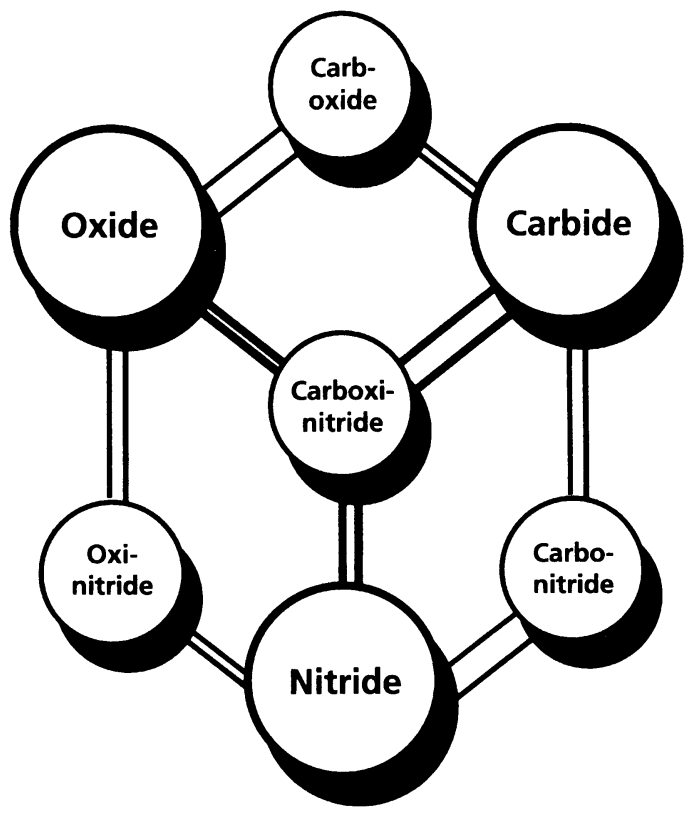

図 1 Material Groups 
アイン・セラミックのみが設計の原理を経済的に実用 化させることが出来るのである。

ペーパー・マシンのワイヤー・パートとプレス・パ 一トのアルミナ系セラミックは長い間最高級品を代表 してきた。金属酸化物を主成分とするもので, 最も重 要且つ代表的なものはアルミナ系セラミックである。 読者もこのものの知識と, 又これをぺーパー・マシン に使用した経験があるはずと思う。1980 年代の初め まではこのセラミックは長網抄紙機のワイヤー・パー トとプレスのセラミックに対する要求を全て満たして きた。しかしながら，曲線状の脱水機器をもった最初 のハイブリッド・フォーマーが使用され，まったく新 しい事態が起った。すべての関係者は, アルミナ系七 ラミックはもはや新しい要求には応じられないことを, 認めざるを得なくなった。その理由と結論を次に述べ る。

先ず第一に，ペーパー・マシン・デザイナーと製紙 会社は，更に抄速を上げ，そして常に紙の品質向上を 望む市場の要求に応えるためには, 曲線状の脱水機器 が必要であるということで意見が一致している。この 要求は, 我々セラミック専門家にとって大きな挑戦で ある。何故ならアルミナ系セラミックは, 本質的に限 界にきてしまったことを認めざるを得なかったからで ある。

\section{1 熱疲労抵抗の測定}

新しい特性をもつたファイン・セラミックが要求さ れるようになって，重大な局面が到来した。ここ数年， しばしば討議されたこの新しい特性の一つは, 熱疲労 抵抗である。これこそ新しいファイン・セラミックが 曲線状脱水シュー, 又はプレスの各種サクション・チ ューブ，特にシュー・プレスに使用できるであろうと 考えた主要な決定要因である。

ファイン・セラミックの熱疲労抵抗は図 2 に示すよ うに, サーマル・ストレス・パラメーター（熱応力特 性値）によって測定される。

最も重要な数値は：

・破壊点における応力 $\sigma \mathrm{B}$

- 膨張係数 $\alpha$

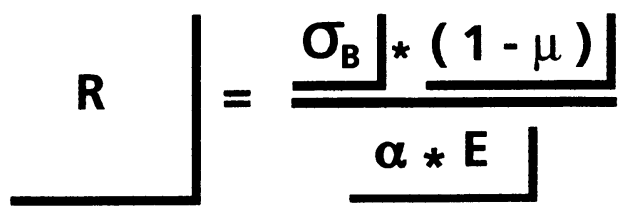

図 2 Thermal Stress Factor
・そしてセラミックのヤング率 $\mathrm{E}$

もう少し明瞭に表現すると Rはセラミックがクラ ックを起こさないで耐えられる温度差である。何故に より高い熱疲労抵抗が求められ, そして何故にそれが 要求されるか, ストリップ・サクション・ボックス・ カバー 3 本を使って説明する。

\section{2 摩擦熱の発生と応力ひずみ}

摩擦熱は図 3 が示すようにカバーの表面で起る。こ の熱はワイヤー及びフェルトが運転されることで起る。 摩擦熱はあなたが手のひらをこすっても起る。より強 く,より速くこすれば，摩擦による発熱量は次の場合 により多くなる。すなわち

(1)ワイヤー及びフェルトのスピードの増加

(2)サクション・ボックスの増加

(3)ワイヤー及びフェルトとカバーの摩擦係数の増加 である。

摩擦係数がワイヤー及びフェルトとカバーの間の水 の量に, 強く影響を受けるということは常識になって いる。理論的には摩擦力, 例えばカバーに沿ってワイ ヤー及びフェルトを引つ張るのに必要な力についても 同じことが言える。罒 3 が示すように, カバーの表面 に起る摩擦熱によりカバーは温められ, それにより起 る熱は非常に高温になることがある。又，そのために ワイヤー及びフェルトの糸が溶けてしまうことがある。 セラミック・カバーの幅方向に拡がる速さは材質の 熱の伝導率により決まる。もつと簡単に言えば, カバ

Friction Losses
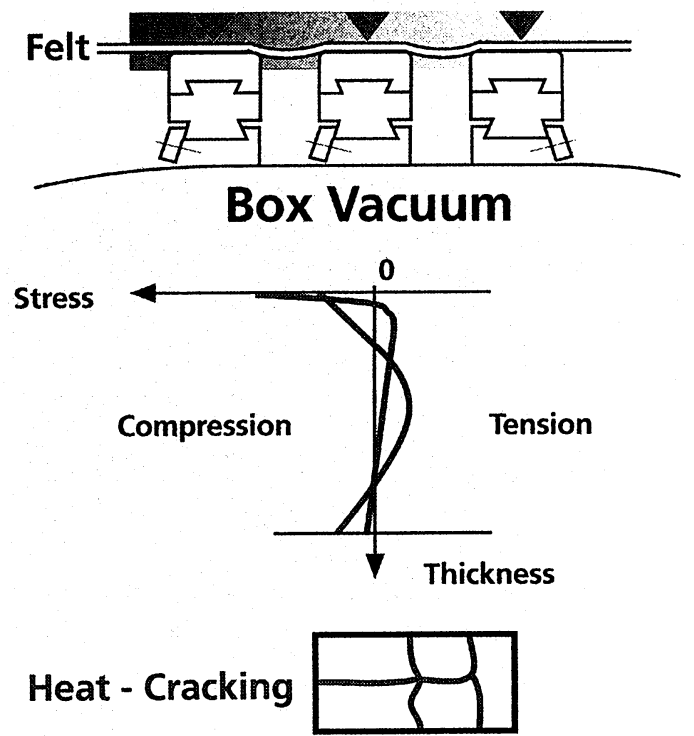

図 3 Dry-Run 
一の熱伝導が増せば，カバーの表面に起る熱の幅方向 の伝達も速くなる。熱伝導率が悪ければ，伝達も遅く なる。金属サクション・チューブの応力ひずみ曲線と, セラミック・サクション・チューブの比較をしてみる。 金属の場合，幅方向の下側の温度と，上側の温度が同 じになるのに長くはかからない。又，表面に生じな熱 は極好短時間で幅方向に伝達するからである。結果 として压縮応力と引張応力は, 殆ど均一に幅方向に伝 達する。上部と下部の表面の圧縮応力は実際には同じ である。かくして㐫力の差はないのである。

ファイン・セラミック・サクション・チューブの応 力ひずみ曲線は，全く異なっているように見える。セ ラミックが熱の不良導体であることは誰でも知ってい る。材料にもよるが，熱伝導は鉄に較べ 20 30 倍小 さいのである。カバーの表面に生じた熱は幅方向に非 常にゆっくり伝達する。そのためにカバーの上部と下 部の間には大きな温度差が生じ, その結果, 大きな膨 張差及び応力差が生じる。スライドが示すようにこれ が圧縮応力である。

\section{3 ヒートクラックの発生}

そして均質でないファイン・セラミックでは, 物理 学の法則をひっくり返すようなことが起るので，次の ようなことも当てはまる。もしセラミックに加えられ たひずみ量がその物の耐応力よりも大きい場合は損傷 が起る。これがクラックである。これらの損傷は全幅 方向に瓦って直線的に走る。それは明らかに材質の特 性によるもので，我々はヒート・クラックと言う。

しかしながら実際の問題として, どのような操業条 件の時にこのような損傷が起ると思われるだろうか？ 我々が見てきたように, セラミック機器の温度差が大 きくなるにつれて，ヒート・クラックの危険が増大す る。我々の経験ではもしペーパー・マシンを，ドラ イ・ランニング状態で操業速度までスピード・アップ するとワイヤー或いはフェルトがセラミック・カバー の表面に大量の摩擦熱を発生させる。これがヒート・ クラックの主因である。最近の経験ではドライ・ラン ニングは少なくなっていると思うが，スプレイ・パイ プ等を設置するとか，準備万全を期しても全く無くな ったわけではない。我々はこのような事故とは共存し て行かねばならないと思う。しかしながら，我々のシ ュミレーターでの実験では, 反対にドライ・ランニン グは必ずしもヒート・クラックを引き起こすことはな いということが分かった。

マシンが短時間停止した場合は，実際には依然とし て操業時の温度であり, 七ラミックの温度もある程度 本体の温度と同じである。もしこのようなマシンのス
タート・アップの時ドライ・ランニングが起り，そし て操業速度までに達したら，七ラミック・カバーの温 度は全く同じである。しかし，ドライ・ライニングが 制御して行われれば，予防することは実際に可能であ る。制御するとはマシン・スピードをゆっくり增速す ることである。ドライ・ランニングによって単位時間 に発生する熱は，マシンを急速に操業速度まで増速す る時よりも少ないのである。

更に，摩擦熱がセラミック全幅に均一に拡散するに は，かなり時間がかかる。この場合クラックを引き起 こすストレス・ピーク (応力の頂点) なるものはない。 しかしセラミックがこの方法でドライ・ランニングを 乗り切っても，クラッキングは依然として起り得る。 そしてその損傷程度は前に述べたヒート・クラックよ りも，もっと悪い。摩擦で加熱されたセラミック・カ バーが急激に冷却されると表面のクラックは破裂する ことがある。また洗浄のためにセラミックに冷却水を 吹きかけた時などに起る。

セラミックの専門家として図 4 に示すようなサーマ ル・ショック・クラックについても述べなければなら ない。多くの小さなマイクロ・クラックを読者はガラ 又製品の俗に言う網状ひび割れ焼で理解できるであろ う。クラックの原因となる幅方向の応力差はヒーティ ングによる応力差とほとんど同じである。しかしすべ て逆の事が起きている。すなわちマイクロ・クラック は引っ張り応力により起り, 圧縮応力ではないという ものである。専門家は個々のケースでクラックがヒー

\section{Cold Water}
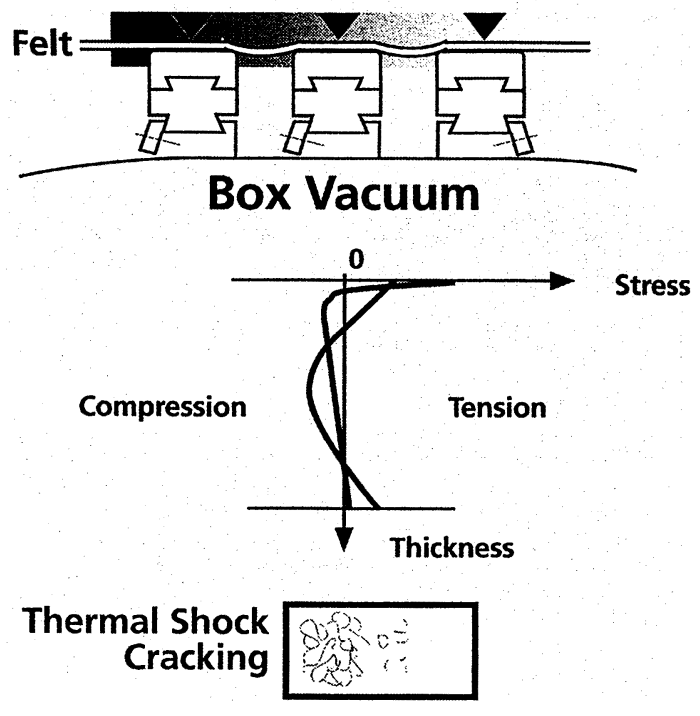

図 4 Thermo-Shock 
ティングによるものか，急激な冷却によるものかが見 分けられるのである。

\section{4 セラミックカバー表面温度の測定}

ワイヤー・パートとかプレス・パートのセラミッ ク・カバーの表面の温度を確かめるために, 我々はシ ュミレーター・テストを実施し, 熱電対で測定した。 図 5 は曲線状の面をもった脱水シューを示している。 現在すべてのハイブリッド・フォーマーやギャップ・ フォーマーに見られるものである。

セラミック・カバー表面の温度は次の三つの要素で 決まることがわかった。すなわち

・曲率半径

・接触角度

・二つのワイヤーのワイヤー・テンション

である。潤滑シャワーを用いてワイヤー・スピードが 毎分 800 メートルの時, わずか 3 分後にアウトレッ ト・ストリップの表面温度は $190^{\circ} \mathrm{C}$ と測定された。

サクション・チューブ・カバーのプレス・シミュレ ーターによる温度測定で, ペーパー・マシンのワイヤ ー・パートより更に一層高い温度がプレス・パートで 生じることも確認された。フエルトのスピードが毎分 $1,000 \times$ 一トルの時は, 温度 $200^{\circ} \mathrm{C}$ が測定され, そし

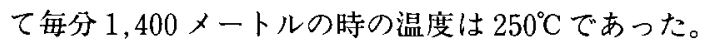
2-スリット・チューブ・カバーの測定結果は，たいへ ん興味深いものである。

また， 3 本のサクション・チューブ・ストリップで は明らかに独特な温度を示す。そして 2 本目と 3 本目 のストリップの温度は, 1 本目のストリップより大幅 に高いことも注目に值する。

上述のことから, 熱㐫力ファクター（係数）はペー

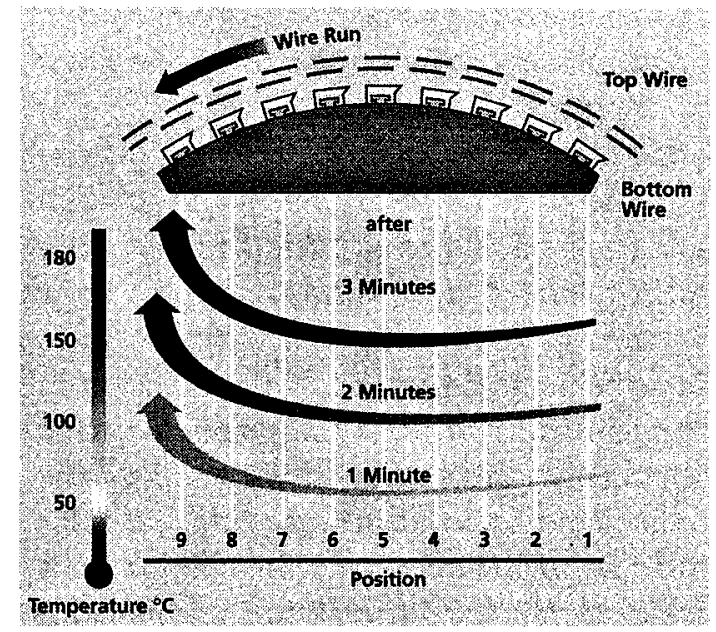

図 5 Surface Temperature Curved Shoe
パー・アシンのセラミックの材質を選択する上で，現 在非常に重要な判断基準であると結論づけることがで きる。

\section{3. ファインセラミックスの選択}

\section{1 ファインセラミックスの種類と特性}

図6で現在のファイン・セラミック材は, きわめて 価值ある熱応力ファクターを有していることが分かる。 現在これらのファイン・セラミック材は, 下記の何種 類かの紙のペーパー・マシンのマシンのスピード記録 を更新したハイ・スピード・ペーパー・マシンにおい て，すべての機能を満足させている。すなわち

・新聞 用紙: 抄速 毎分 1,652 メートル

- 蒤工原紙：抄速 毎分 1,625 メートル

-上 質 紙：抄速 毎分 $1,310 x-ト ル$

・軽量コート紙：抄速 毎分 1,527 メートル である。

これらの抄紙プラントでは, ペーパー・マシン・デ ザイナーと製紙会社は，どのセラミックをぺーパー・ マシンのどのポジションで，そして，とりわけ経済性， 操業性, そして作業性についての判断基準によって決 める。セラミック・カバーのメーカーとして, 我々は 上記のペーパー・マシン・スピードは, 引き続き上昇 すると考えている。

更に意志決定の要因, 例之ば表面の品質, より卓越 しな硬度，より優れた強鞄性が疑いなく重要さを増す と思われる。又, 特に炭酸カルシウムを使用する上質 紙用ペーパー・マシンの改造或いは新設で，大いに関 連のある論題はワイヤ一の摩耗である。我々はこの分 野での最も新しい開発について簢単に説明する。

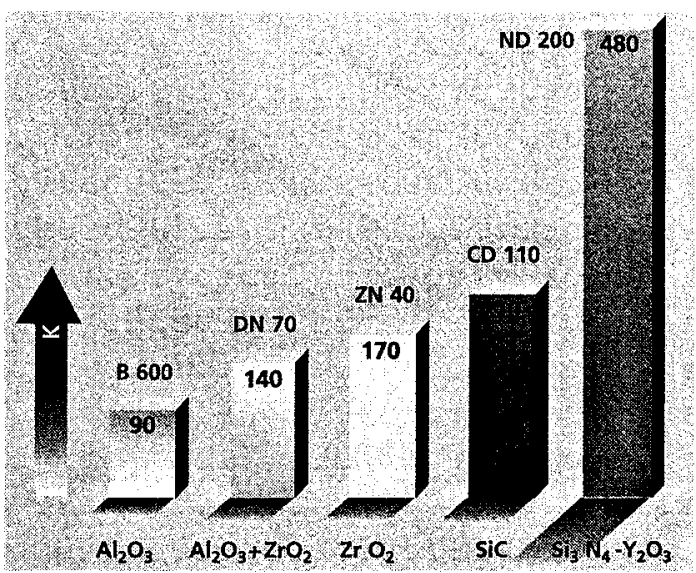

図 6 Thermal Stress Factor 


\section{2 堤料と摩耗性}

摩耗が起るメカニズムには問題解決の手がかりとな る要因がある。もし摩耗の損害を調査する必要があれ ば，ワイヤー，セラミック・カバーそして填料は詳細 に検討しなければならない（図7）。

摩耗の学説・体系には, 摩耗のメカニズムを決定す るその他の特性が数多く存在する。この体系全体につ いて検討するのは与えられた紙面では不可能であるか ら, 我々はペーパー・マシン用ファイン・セラミッ ク・カバーの表面の品質にとって重要な調査結果に限 つて検討する。

現在まで,ファイン・セラミックの表面の定義づけ は，主として面粗度と凹凸を測定することであったが， ファイン・セラミックには永い間よく知られた特性の 数值を正確に測定する方法がある。ここ数年来, ドイ ツ紙パルプ技術協会のフィラー・ピグメント・グルー プが開発を進めてきた摩耗の新しいテスト機器により, ファイン・セラミックのポロスィティー (空隙率) が 摩耗のメカニズムで, 重要な役割を演じていることが 分かった。それ故我々はポロスィティーを見つけて測 定する方法について簡単に論じたい。

\section{3 ファインセラミックス表面空隙率}

分散セラミック・カバーの表面をインタラクティブ (相互作用) イメージ (画像) 分析システムにより表 面ポロスィティーの測定をする。システムは小さな孔 を記録・計算し，孔径毎に分級する。一例を示すと 730 個のうち 30 個の小さな孔がある。730個のうち

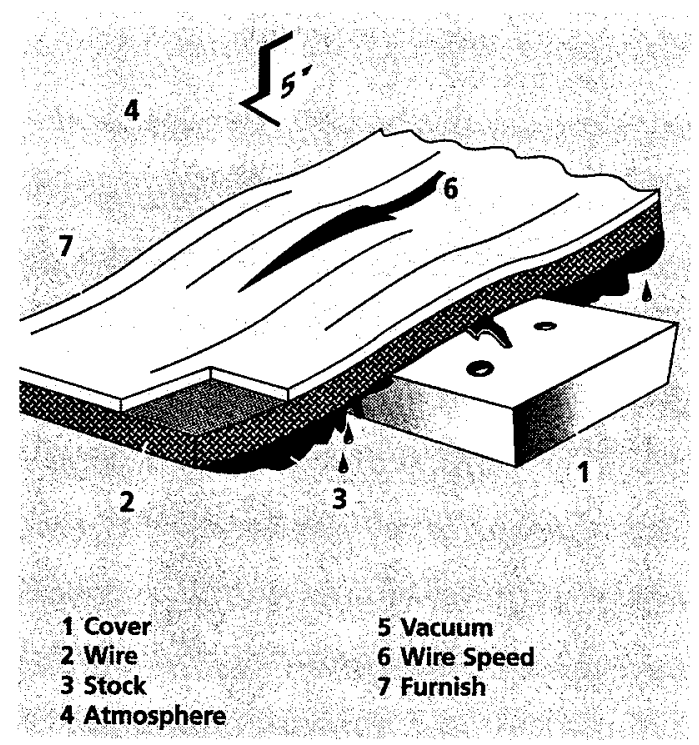

図 7 Wear System
30 個は分級のクラス 2,すなわち孔径は1.259-1.585 ミクロンなどである。全ての小さな孔の $50 \%$ 中央 值は分級のクラス 6, すなわち孔径 3.1163-3.981 ミ クロンである。小孔の直径平均，すなわちすべての記 録・測定された小さな孔の算術平均值は 4.866 ミクロ ンになる。セラミック機器の小さな孔の表面の平均值 を\%で表わすので，セラミック・カバーの接触面積の 此率 (\%) は計算出来る。

ガウスのディストリビューション・カーブ (分散曲 線) で，上記に述べたディスバージョン (分散) セラ ミックと，標隼的なアルミナ系セラミックのポロスィ ティー（多孔率）を直接比較する。また標準的なアル ミナ系セラミックのポロスィティーを窒化硅素セラミ ックのそれとの比較もする。直接比較するだけで，両 者のセラミック・カバー表面のポロスィティーにかな りの違いのあることがはっきりと分かる。

セラミック・カバーと填料の相互作用, すなわちワ イヤーの摩耗への影響をよりよく評価・算定するため に，填料に関する追加の資料を必要とする。

\section{4 填料とファインセラミックスの評価}

ご存じのように填料は何時も同じ填料ではない。現 在填料或いは塗料として使用されているカオリン， 夕 クル或いは炭酸カルシウムの何であれ, 製紙用として の品質は製造プロセスで決まる。炭酸カルシウムを使 用する中性紙の操業を思い出して頂きたい。炭酸カル シウムのような填料は付着する位置, 原料, 形態・構 造, 硬度, 粒度分布が著しく变わることがあるので, 注意しなければならない。原料の硬度と形態・構造の 他に, 塡料特に炭酸カルシウムでワイヤーの摩耗に影 響する最も重要なものは粒度と粒度分布である。ワイ ヤーとセラミック・カバーの表面の間を移動する堙料 の粒子のサイズを測定することも可能である。

\section{5 コンピューターによるファインセラミックス の選定}

我々は摩耗の過程を表現すべくコンピューター処理 装置を開発した。これらの資料を用いて，ファイン・ セラミック・カバーが極めて異なったポロスィティー, そしてとりわけ異なったサイズの小さな孔の表面を持 つことが出来るのが分かるのである。こうして，もし 我々が填料の粒度を知れば，塤料の粒子はセラミッ ク・カバーの表面の小さな孔より大きいか，おおよそ 同し大きさか, 或いは小さいかも分かるのである。

このようにして，もし填料の粒子が小さな孔より小 さければ, 粒子はセラミックの表面の小さな孔に落ち 込み，また粒子のサイズがほぼ同じなら粒子は小さな 孔に滞留するか，或いは粒子が小さな孔より大きけれ 
ば粒子は小さな孔の間を越えて移動する。

ワイヤーの摩耗は相对速度により大きく決まるので， 我々はペーパー・マシンでの摩耗のメカニズム, すな わち七ラミック・カバーと塡料, そしてワイヤーの相 百作用を IBAS 测定法によってより良く理解するこ とが出来る。例えばファイン・セラミックの表面の小 さな孔が填料の粒度に適合するとか, 或いは填料の粒 沒がファイン・セラミック・カバーの表面の小さな孔 に適合寸るのか分かるのである。
二つの測定には，ワイヤ一の摩耗を減らす，或いは 最大限に利用するとか, ペーパー・マシンの駆動用動 力を減少させるという目的がある。

現在，坥料やワイヤーのメーカーと同様に，七ラミ ック・メーカーは新しいペーパー・マシンで, より菂 い生産性を達成するために, 製紙業界の積極的な文持 と協力を得ながら，大きな貢献をすることが出来ると 確信するものである。 